\title{
Reading is very important, but...: Taking stock of South African student teachers' reading habits
}

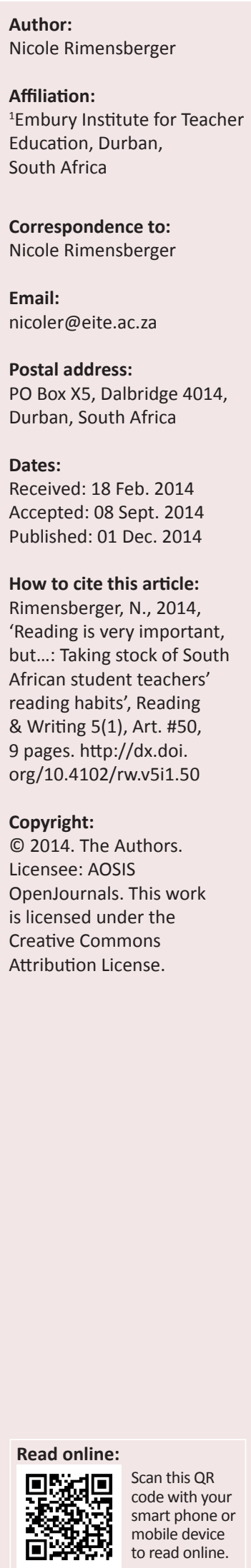

This article explores the contradiction between student teachers' acknowledgement of the importance of reading and their actual personal reading habits, and by doing so, attempts to dig below the surface and 'take stock' of future teachers' attitudes towards reading at a private tertiary institution in Durban, South Africa. The rationale is that without fully understanding student teachers' own attitudes towards reading, the challenges of literacy and reading in the classroom cannot be fully addressed. It does this through a survey of 171 student teachers that investigated how much or how little they read for pleasure, what texts they read for pleasure (fiction, non-fiction, magazines, newspapers, online), how many of them are engaged readers of extended texts (fiction and non-fiction) and finally, the role books and reading play in their lives. It emerged that student teachers' positive attitude towards reading and their apparent understanding of its importance starkly contradicted their lack of own reading for pleasure and investment of their time in this activity. The acknowledgement of the importance of reading can be viewed as a small success. However, it is ultimately overshadowed by the reality that if this contradiction is not pointed out and interrupted, it could send a mixed message to future learners: that reading is important, but not pleasurable.

\section{Introduction}

Through exploring the contradiction between student teachers' acknowledgement of the importance of reading and their personal reading habits, this article is an attempt to take stock of future teachers' attitudes towards reading. It does this through seeking answers to the questions how much student teachers read for pleasure, what types of texts they read and what role reading and books play in their lives. The rationale is that without fully understanding student teachers' own attitudes towards reading, the challenges of literacy and reading in the classroom cannot be fully addressed. Little research has been conducted on South African student teachers' reading habits and, as a result, this article reflects on the local situation in relation to international research.

Internationally, studies have found that reading for pleasure is in decline (Gallagher 2009, Mokhtari, Reichard \& Gardner 2009; National Endowment for the Arts [NEA] 2007). Mokhtari et al. (2009) examine the impact of Internet and television use on the reading habits and practices of 539 college students at a Midwestern university. They found that students rated recreational reading as important (60\% rated it as extremely important) yet did not seem to actively pursue recreational reading and seemed willing to forgo it for other activities, such as academic reading, internet usage and television (Mokhtari et al. 2009:617). A similar decline was noted by the NEA (2007:7) which collated national data to create a reliable and comprehensive picture of American reading habits. It was found that nearly half of all Americans aged 18-24 did not read books for pleasure.

The South African situation is compounded, firstly, by the relatively small reading population where many who can and have the means to read, choose not to read books. Secondly, it is compounded by a schooling system that is not producing children with functional literacy. For example, the Proficiency in International Reading Literacy Study (PIRLS 2006 and 2011), an international benchmark test for Grade 4 and Grade 5 learners, indicates that literacy levels in South Africa are poor, lagging behind other countries. In addition it found that:

- Grade 4 learners, especially those tested in African languages, achieved well below the International Centre point despite writing an easier assessment in 2011.

- Forty-three percent were unable to reach the Lowest International benchmarks for reading and only $4 \%$ could reach the Advanced International benchmark (compared to $8 \%$ internationally) (Howie et al. 2012:112-113).

Providing children with positive reading role models is one aspect of addressing this problem and connects student teachers' reading habits with future good practice. Thomas (2012:30) 
argues that, particularly in educational research, knowledge should be seen as coming from immersion and informed reflection on practice. This study is firmly rooted within an understanding of educational research as research situated in practice. The current study was therefore informed by interactions and observations of students at a small, private institution focused exclusively on teacher training through my own teaching of an English course in the foundation phase programme.

Various initiatives from the private sector, governmental and non-governmental organisations and bodies have attempted to address the poor literacy levels as well as counter the decline in reading for pleasure. A further aim of these initiatives is to foster the growth of a culture of reading through targeted interventions (Reading Association of South Africa [RASA] 2012; READ 2010), a National Book Week (South African Book Development Council 2012), creating more libraries and supplying books to underprivileged communities (Room to Read 2012), as well as supporting teachers and librarians (Centre for the Book 2012; RASA 2012; READ 2010). All these initiatives acknowledge that the development of reading and literacy have a positive impact on educational results and improving overall life opportunities (Book Development Council 2012; Centre for the Book 2012; RASA 2012, Room to Read 2012; READ Educational Trust 2010).

Whilst literacy is afforded much importance and time by government and teachers because of poor learner performance (PIRLS 2011), the promotion of readership as a necessary, and equally important, extension of literacy has often been neglected. This point is particularly salient in my context of foundation phase education and raises the question: is literacy our only goal or do we adequately make student teachers aware of their role in promoting the reading that comes after literacy?

A further effect of the poor performance of South African learners in benchmark tests such as PIRLS and the interventions offered by key role players, is that the overall message that reading is important is becoming louder. The current study revealed that this message had indeed been heard, but not sufficiently internalised to change personal reading habits. This is worrying, especially amongst student teachers, as the need to be passionate, particularly in the foundation phase, about narratives and stories is so important in starting children on the journey to becoming readers.

\section{Teachers as readers}

A review of the literature reveals that the issue of teachers as good role models for reading has long been a point of academic interest (Mour 1977; Mueller 1973). Recent studies have further established the importance of good adult reading habits as a positive model for children (Applegate \& Applegate 2004; Benevides \& Peterson 2010; Brown 2009; Du Toit 2001; McKool \& Gespass 2009). Teachers who read for pleasure are more likely to choose appropriate reading strategies in their classrooms and present better models for reading (Benevides \& Peterson 2010, Burgess et al. 2011; McKool \& Gespass 2009). Consequently, Benevides and Peterson (2010:291) point out that, 'Pre-service teachers who do not bring an enthusiasm for reading and engage in free-choice reading on a regular basis may find it difficult to model a love of reading'.

Despite acknowledging this importance, Benevides and Peterson (2010:298) observe that student teachers tend not to be enthusiastic readers. This study is motivated by a similar concern that within an already fragile education system, reading must be viewed as a valuable resource particularly in teacher education and therefore it is important to regularly take stock of this resource.

The contradiction between student teachers' acknowledgment of reading as a valuable activity and their lack of own reading for pleasure is not new. Applegate and Applegate (2004) refer to this contradiction as the 'Peter effect' from the biblical story of the apostle, Peter. In this story, Peter is unable to give a beggar any money because he 'could not give what he did not have'. Applegate and Applegate (2004) state:

Nearly all reading experts now agree that both skill and will must be considered in the conceptualisation of the ideal reader, the one with broad interests who samples widely and deeply from available sources of text and is motivated to read on a regular basis. (p. 554)

This again reminds us of the importance of engaged and intrinsically motivated readers and the impact this has on increased reading ability and increased text comprehension, two factors which are linked to greater academic success. Intrinsically motivated readers engage in reading for its own sake and to satisfy their own curiosity (Applegate \& Applegate 2004:554). They argue that teachers must create a classroom environment which encourages the growth of such readers. This becomes difficult when they do not love reading themselves, and, as Peter in the Bible story, they cannot 'give what they do not have' (Applegate \& Applegate 2004:556).

Applegate and Applegate (2004) discuss the notion of aesthetic and efferent stances in relation to the reader and the text:

In the aesthetic stance readers become absorbed in the text and live through the experiences of others. In contrast, the efferent stance has its primary emphasis in the ability to acquire and retrieve information. (p. 555)

The efferent stance is sufficient for purposes other than recreational reading. However, being an engaged and enthusiastic (aesthetic) or transactional (efferent) reader has clear implications in the classroom. Teachers' views of reading will indirectly affect their choice of instructional strategies that are used in the classroom which will, in turn, influence the level of engagement of children with the reading material (Benevides \& Peterson 2010; McKool \& Gespass 2009). It is the intention of the current study to examine student 
teachers' reading habits in relation to enthusiastic and transactional reading patterns.

The current study further underlines the importance of reading role models for developing reading habits in children. Much of this role-modelling is centred around engagement with reading for pleasure. According to McKool and Gespass (2009):

more recently the explicit teaching of reading strategies has made its way into the forefront of policy makers and curriculum developers. While explicit teaching of skills and strategies is useful and necessary as a component of reading instruction, this explicit teaching without allowing for sufficient practice through independent reading is counter-productive. (p. 265)

Brown (2009) makes this point in her paper 'Harry Potter and the reluctant reader' which discusses the role of popular children's fiction in developing children's reading fluency. Full emergence in the world of reading requires far more than simply a mechanical process of decoding signs (the alphabet) that represent words. This makes us ask: is reading simply a skill or is it something more? To be a 'reader' implies not just someone who 'can read', but perhaps someone who 'does read' based on some intrinsic motivation. Brown (2009:50) argues that 'something more' means attaining a level of fluency that crosses the bridge from effort to ease and results in a kind of insatiable hunger for more. A reason for the failure of so many of our learners to acquire true reading fluency, as evident in the PIRLS results, is that it requires sustained effort. This makes a strong argument for the value of intrinsic motivation being a key factor for children to practice reading on their own.

Brown (2009) points out the importance of adults modelling enjoyment of reading in motivating learners to view reading as pleasurable and therefore worth the effort to attain fluency. This was shown to have a much greater impact on children's perceptions of the pleasures of reading than simply telling children to read. In reality, however, South African teachers are questionable models for good reading practice. According to Howie et al. 'the PIRLS study showed that South African teachers read less often in their spare time compared to those in the highest achieving countries' (see Brown 2009:50). The current study confirms this.

\section{Methodology}

This study took its shape and form from the following questions: firstly, how much (or little) do student teachers read for pleasure; secondly, what texts are they reading for pleasure (fiction, non-fiction, magazines, newspapers, online); thirdly, how many are engaged readers of extended texts (fiction and non-fiction); and finally, what role do books and reading play in their lives? Thomas (2012:40) argues that methods used in educational research should emerge from questions, rather than being prescribed in advance. He advocates methods as being the servants to questions and not the other way around (Thomas 2012:38).
The study made use of two instruments to gather data through two collection points. Firstly, a survey questionnaire was completed and returned by 171 students of a total sampling unit of 249 registered for a first year English course. This survey took place at the beginning of 2012. Secondly, an instrument asking students to list what they had read during the June and July holidays followed mid-year and tracked the same students who had responded to the initial survey. Together the two instruments were used to triangulate the responses about reading attitudes and habits. They have been included as Appendix A and Appendix B.

A limitation of reading research is that it depends on selfreported data and participants frequently respond to questions with what they believe is the 'right' response (McKool \& Gespass 2009:272). To minimise this and ensure greater reliability of the data reported, the study relied on cross-checking participants' responses. This was carried out between questions in the survey as well as between the two data collection points. For example, a respondent who strongly agreed on an ordinal scale survey question that they loved reading could be cross-checked against what they reported actually reading during the holidays through the second instrument. This provided more reliable quantitative data on reading habits and attitudes.

Both quantitative and qualitative methods of analysis were used. The survey questionnaire responses were tabulated and analysed using Microsoft Excel ${ }^{\circledR}$. Responses from an openended question in the survey on the role that reading and books played were coded into four types, which were lifted from initial readings of the data. All comments were then classified according to these types. Coded and tabulated data were converted to percentage points for reporting purposes.

All respondents were required to sign an informed consent form and were free to refuse to participate in the study. As names needed to be tracked to link the data from two collection points, all respondents were given a number and a key was stored in a safe place in order to ensure confidentiality and anonymity for participants.

Whilst the study does not claim to investigate a new problem, or indeed seek an easily generalisable solution to the issue of reading amongst student teachers, it is in a particular, localised context, seeking to further a practical understanding of the problem by 'explaining through the construction of potential narratives' (Thomas 2012:42). In this case, the study, through a mixed method approach, established a contradictory narrative between what student teachers say about reading and their own reading habits.

\section{Findings \\ Attitude towards reading}

Analysis began with a review of reading attitudes and then attempted to draw out in more detail how this related to personal reading habits. Respondents were asked to agree or disagree with the following statements: 'I love to read' and 'I only read books when I have to for school or university'. 
Responses are shown in percentages in Figure 1 and Figure 2. Responses to 'I love to read' (Figure 1) indicated significantly more positive than negative responses, although most $(40 \%)$ indicated that they felt neutral about the statement. Responses to 'I only really read books when I have to for school or university' (Figure 2) supported this positive picture. The majority (32\%) disagreed with the statement, $25 \%$ were neutral and $16 \%$ responded, 'strongly disagree'.

\section{Reading habits: Frequency of reading for pleasure}

Respondents were asked how often they read for pleasure. Responses, shown in Figure 3, indicate that only 16\% read every day, $26 \%$ read once or twice a week and $33 \%$ read for pleasure every few months. This shows that positive reading attitudes do not necessarily translate into daily reading practice or are any indication of being what Applegate and Applegate (2004:554) refer to as an aesthetic reader.

This particular question did not distinguish text types, so to establish reading frequency related to different types of text, respondents were asked to indicate when they last read a particular text type. Results are shown in Table 1.

Numbers in bold indicate the most common response and in italics the second most common. Together they show the most frequently read text type. Table 1 clearly shows that extended texts such as novels and non-fiction books are read infrequently by most, whilst shorter texts such as magazines, newspapers and online reading (which included blogs, websites, social media sites - mainly Facebook and Twitter, etc.) are read more frequently.

Whilst reading for pleasure could entail many different types of texts, from magazines to blogs, it was decided to focus on extended texts such as novels and non-fiction books as this is the type of reading that needs to be modelled for children. For analysis purposes the two were combined and revealed that $66 \%$ of respondents read extended texts infrequently (a few months to a year ago or so long ago that they could not remember exactly when) and 19\% had read an extended text within the last two weeks. Interestingly, at the time of the study in February 2012, only 12\% were reading an extended text.

\section{Reading habits: Favourite book and last read books}

The next section details what respondents' favourite novel and last read novel were and through this, explores reading habits and patterns to indicate overall engagement with books. It was found that $26 \%$ could not name a title or author of their favourite book apart from broad genres such as love stories or horror, which were not counted. Seventy-four percent could name a title or author who was their favourite. However, of this group, $17 \%$ had named either a Shakespeare play, other well-known school set books or a current textbook as their favourite.
In terms of what book respondents had last read, 17\% did not respond or could not name the book they had last read. Some interesting things to note about the remaining $83 \%$ of responses were that $15 \%$ named a school set book (such as a Shakespeare play or Animal farm by George Orwell) and $36 \%$ named the same book they had for the question on favourite book.

This could be interpreted to mean that students have a limited engagement with books. Of course, one cannot say that students did not find favourites in their school set works or that the last book they had read was not indeed

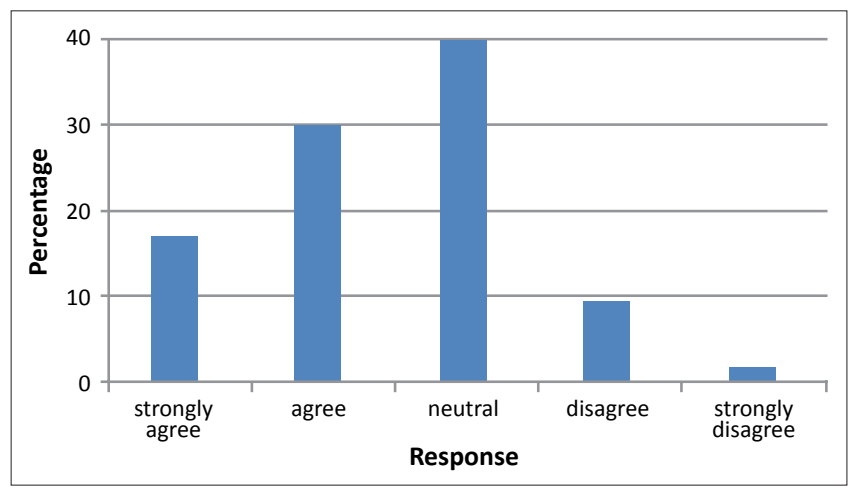

FIGURE 1: 'I love to read'.

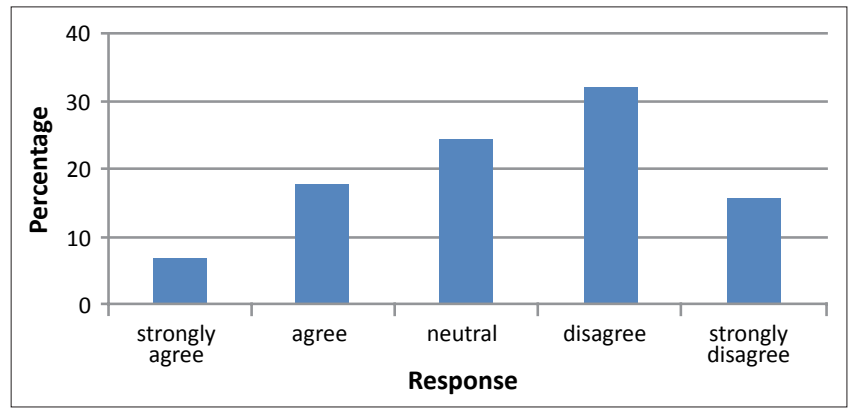

FIGURE 2: 'I only read books when I have to'.

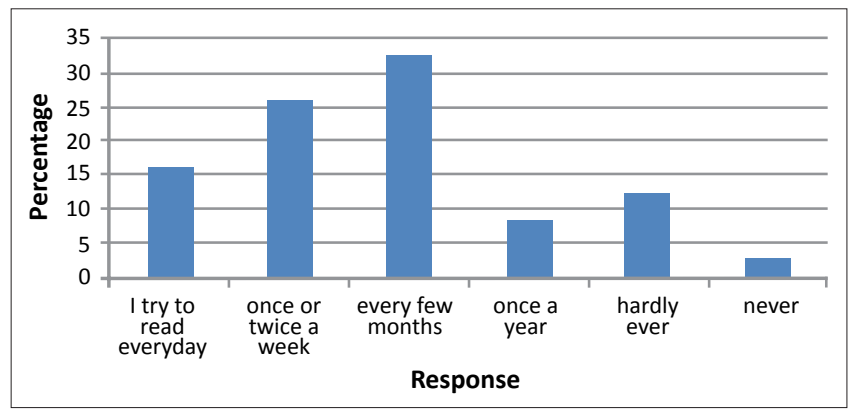

FIGURE 3: Self-reported frequency of reading for pleasure.

TABLE 1: Frequency in relation to text type.

\begin{tabular}{lcccccc}
\hline Text type & \multicolumn{1}{c}{ Frequently } & - & - & & & \\
\cline { 2 - 7 } & $\mathbf{1}(\mathbf{\%})$ & $\mathbf{2 ( \% )}$ & $\mathbf{3 ( \% )}$ & $\mathbf{4}(\mathbf{\%})$ & $\mathbf{5 ( \% )}$ & $\mathbf{6 ( \% )}$ \\
\hline Novel & 9 & 11 & 17 & $\mathbf{2 7}$ & 18 & 18 \\
Non-fiction & 7 & 11 & 11 & 14 & 22 & $\mathbf{3 5}$ \\
Magazine & $\mathbf{3 7}$ & 33 & 17 & 11 & 1 & 2 \\
Newspaper & $\mathbf{5 7}$ & 19 & 13 & 5 & 1 & 5 \\
Online & $\mathbf{7 5}$ & 11 & 6 & 3 & 0 & 5 \\
\hline
\end{tabular}




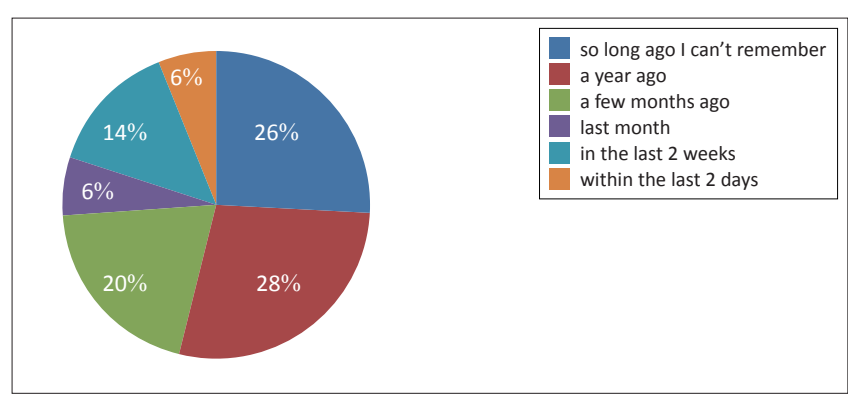

FIGURE 4: When students had read last novel (also named as their favourite).

TABLE 2: Relationship between attitude and holiday reading.

\begin{tabular}{lc}
\hline 'I love to read’ & $\begin{array}{c}\text { Percentage of respondents who read an } \\
\text { extended text during the holidays (\%) }\end{array}$ \\
\hline Strongly agree & 55 \\
Agree & 31 \\
Neutral & 21 \\
Disagree & 6 \\
Strongly disagree & 0 \\
\hline
\end{tabular}

their favourite. However, this seems more unlikely when considering when students last read an extended text. Figure 4 shows an analysis of time frames for the $36 \%$ of respondents who stated their last read book was also their favourite book.

Fifty-four percent last read a book over a year ago. This shows that respondents did not read frequently and that they may have so little interaction with books that they struggled to name two separate titles. This may explain the lack of variety of response about their favourite book and last read book.

\section{Checking reading habits: Holiday reading}

To consolidate information on actual reading habits, respondents were asked what they had read during the June and July holidays. It emerged that only $30 \%$ had read an extended text during that period.

In order to cross-check student reading attitude with their actual reading practice, the relationship between the responses to the statement 'I love to read' in question 1, and what they had actually read during the holidays was explored. Results are shown in Table 2.

On the surface, these results confirm a link between reading attitude and reading habit. However only $55 \%$ of those who responded 'strongly agree' to the statement 'I love to read', had actually read a book, which for students who claim they love reading is very low. This indicates that having a positive reading attitude does not necessarily translate into regular reading.

\section{The role of reading and books}

This section will examine data from a qualitative point of view. The questionnaire allowed an open-ended response on the role reading and books played in student teachers' lives. It was felt that this was important to ask, as, for those intrinsically motivated and enthusiastic readers, books and reading are important and 'present' in daily life. How people talk about books says much about how they value them.
Responses were first divided into negative and positive categories and showed that $81 \%$ made positive comments, $13 \%$ negative comments (such as overtly stating that they did not like reading) and $6 \%$ did not respond. Secondly, four categories or types of responses were lifted from initial readings of the data. All positive responses were then coded into these four types. These are discussed below.

Type 1: 'Trite' responses. Trite responses revealed little personal relationship with reading and were characterised by using depersonalised language such as 'one' or 'you' instead of 'I' which created a sense of distance between the respondents and their attitude to reading. Comments appeared to conform to understanding of the 'correct response' and often listed, in a rather clinical fashion, the benefits of reading, such as improving vocabulary and grammar. Forty-one percent of responses were coded as trite and formed the majority. Examples of responses coded as type 1 include:

'Reading is rather vital in one's life as it builds up our vocabulary. It broadens our knowledge and we become aware of the reality that exists' (Respondent 9). 'Itplaysanimportantroleinone'slife.Itimprovesyourvocabulary, your style of writing and also advances your grammatical style of writing and your speech in a certain language' (Respondent 19). 'Reading is fun. There is always a variety to choose from' (Respondent 98).

Type 2: A means to an end. These responses indicated that reading was a 'means to an end'. Reading was regarded as useful and revealed some personal engagement, but was not characterised by pleasure. This type represents a transactional or efferent stance towards reading. Twentyseven percent were coded in this category.

'Reading has a relaxing effect on me. I read to relax. Reading also helps me keep up on current events and news' (Respondent 70). 'I only read gossip stories or stories about celebrities. It's important when I have a project to do' (Respondent 112). 'It helps me speak better. To understand and imagine my own picture of the story/text I am reading. Reading stimulates my brain. I also gain more knowledge from reading' (Respondent 116).

Type 3: Limited enjoyment. These responses revealed enjoyment of reading at a personal level, but engagement was limited by, for example, too little time, having too much work to do or not finding the right type of book. Sixteen percent were coded limited. The following are typical examples from this category:

'Once I find an author that I enjoy I will read all her novels she has written. I do not enjoy novels that you have to think deep and has hidden meanings. I enjoy easy reads' (Respondent 25). 'I battle reading but when I have a good book I really enjoy reading the book. I wish I read more' (Respondent 41). 'I enjoy to read but I battle to find the time to read because I have a lot of things going on during the day. I would like to take more time out to read. I think it is important' (Respondent 147).

Type 4: A love of reading. These responses showed a genuinely personal relationship with reading that was experienced as a pleasurable and meaningful activity. Whilst aspects were sometimes shared with the other types, what 
distinguished these responses was a clear sense of excitement and passion. Sixteen percent were coded as having 'a love of reading' and could be seen as enthusiastic readers.

'I love to read any book that is written by Nicholas Sparks and Frances Rivers. They both are brilliant authors! I always feel emotional while reading their books! It also links to the reality' (Respondent 64). 'I love reading. It's like a different world with new adventures. Sometimes it [is] like your own TV because you can imagine what [is] going on in the book' (Respondent 158). 'Reading is my way of relaxing. I really enjoy reading. I am a huge fan of love stories. Reading gives you a choice to get away from reality. I read as often as I can although it's been difficult because I have been very busy' (Respondent 40).

\section{Discussion}

Student teachers' reading habits revealed that reading for pleasure was mostly limited to shorter texts such as magazines, newspapers and online reading (chiefly social media). For the purposes of this study, extended texts such as fiction and non-fiction books were focused on and it was found that these were read infrequently to the point that, for most, they had little day-to-day engagement that was characterised by pleasure.

It was also the intention to examine this particular sample of students in terms of engaged and enthusiastic or transactional reading patterns as discussed by Applegate and Applegate (2004). The qualitative analysis revealed that $16 \%$ could be classified as enthusiastic and engaged readers who read frequently and for its own sake, whilst $27 \%$ could be classified as transactional readers who primarily read as 'a means to an end'. Trite responses and limited enjoyment present two further categories which do not completely fit into the efferent and/or aesthetic distinction. Whilst the $16 \%$ who could be classified as having a limited enjoyment of reading might, given more direction and inspiration, become more avid readers, the majority $(41 \%)$ who were coded as trite responses, present a much harder group to reach, as they were particularly disengaged when it came to reading.

Findings concur with international studies which found that student teachers are not avid readers, particularly of extended texts such as novels or non-fiction books (Applegate \& Applegate 2004; Benevides \& Peterson 2010, McKool \& Gespass 2009). This emerged clearly from taking stock of student teachers' reading habits in a particular, localised South African context. To reiterate:

- Sixty-six percent did not read books frequently (last extended text was read a few months to a year ago or so long ago that they could not remember when exactly).

- Only 30\% had read a book during the June and July holiday.

- Only $16 \%$ of the sample could be classified as readers who read for pleasure and enjoyment and as such are enthusiastic readers.

A stark contradiction emerged between students' understanding of the message that reading is important, particularly in an educational context and their own reading habits. Respondents could readily point out the benefits of reading and in many cases responded with positive attitudes about books. This was interpreted as wanting to 'give the right answer'. However, this positive attitude towards reading and apparent understanding of its importance, contradicted their lack of own reading for pleasure and investment of their time in this activity. Ultimately, this contradiction, if not pointed out and interrupted, could send a mixed message to their future learners that reading is important, but not pleasurable and therefore not worth the effort.

\section{Conclusion}

Findings indicate that it cannot be assumed that students studying to be teachers love reading, although it is generally accepted that teachers have the task of encouraging reading in children. Whilst growing emphasis is placed on classroom strategies to engage children in reading, and encourage and nurture the growth of their intrinsic motivation to practice reading, studies such as this show that within teacher education we cannot assume that this is no longer necessary at tertiary level. It demands a back to basics approach for the lecture rooms where we need to draw on creative solutions to inspire our students to read for pleasure as well.

It is up to adults, in this case teachers, to instil a love of reading in children and to be good reading role models for them. However, if we view our student teachers as a future resource, it remains doubtful that they can effectively do this without an intrinsic motivation to read themselves. Attitudes that seem positive on the surface are contradicted by habits that regard reading as a difficult and onerous task. The danger lies in learners seeing behind the surface attitudes and the recursive cycle of reading continuing.

\section{Acknowledgments Competing interests}

The author declares that she has no financial or personal relationship(s) that may have inappropriately influenced her in writing this article.

\section{References}

Applegate, A.J. \& Applegate, M.D., 2004, 'The Peter effect: Reading habits and attitudes of pre-service teachers', The Reading Teacher 57, 554-563.

Benevides, T. \& Peterson, S.S., 2010, 'Literacy attitudes, habits and achievements of future teachers', Journal of Education for Teaching 36(3), 291-302. http://dx.doi. org/10.1080/02607476.2010.497375

Brown, M., 2009, 'Harry Potter and the reluctant reader: Strategies for encouraging reading fluency', Mousaion 27(2), 47-57.

Burgess, S.R., Sargent, S., Smith, M., Hill, N. \& Morrison, S., 2011, 'Teachers' leisure reading habits and knowledge of children's books: Do they relate to the teaching practices of elementary school teachers?', Reading Improvement 48(2), 88-102.

Centre for the Book, 2012, Home, viewed on 12 January 2013, from http://www.nlsa. ac.za/index.php?option=com_content $\&$ view $=$ article $\& i d=53 \& /$ temid $=41$

Du Toit, C.M., 2001, 'The recreational reading habits of adolescent readers: A case study', MA dissertation, University of Pretoria, Pretoria.

Gallagher, K., 2009, Readicide: How schools are killing reading and what you can do about it, Stenhouse Publisher, Portland.

Howie, S.J., Venter, E., Van Staden, S., Zimmerman, L., Long, C., Du Toit, C. et al., 2008, PIRLS 2006 summary report: South African children's reading achievement, University of Pretoria, Pretoria. 
Howie, S., Van Staden, S., Tshele, M., Dowse, C. \& Zimmerman, L., 2012, PIRLS 2011 Summary report: South African children's reading literacy achievement, University of Pretoria Centre for Evaluation and Assessment, Pretoria.

McKool, S.S. \& Gespass, S., 2009, 'Does Johnny's reading teacher love to read? How teachers' personal reading habits affect instructional practice', Literacy Research and Instruction 48, 264-276. http://dx.doi.org/10.1080/19388070802443700

Mokhtari, K., Reichard, C.A. \& Gardner, A., 2009, 'The impact of internet and television use on the reading habits and practices of college students', Journal of Adolescent and Adult Literacy 52(7), 609-619. http://dx.doi.org/10.1598/ JAAL.52.7.6

Mour, S.I., 1977, 'Do teachers read?', The Reading Teacher 30, 397-402.

Mueller, D.L., 1973, 'Teacher attitudes towards reading', Journal of Reading 17, 202-205.
National Endowment for the Arts (NEA), 2007, To read or not to read: A question of national consequence, National Endowment for the Arts, Washington DC.

Reading Association of South Africa, 2012, Home, viewed on 11 January 2013, from http://www.rasa.uct.ac.za/

READ Educational Trust, 2010, Home, viewed 12 January 2013, from http://www.read. co.za/

Room to Read, 2012, Home, viewed on 13 January 2013, from http://www. roomtoread.org/page.aspx?pid=320

South African Book Development Council, 2012, Home, viewed on 12 January 2013, from http://www.sabookcouncil.co.za/reading_promotion.html

Thomas, G., 2012, 'Changing our landscape of inquiry for a new science of education', Harvard Educational Review 82(1), 26-51. 


\section{Appendix A}

Reading survey of first year students (2012)

Cross the appropriate block or write the answer in the space provided (if applicable)

\section{SECTION A:}

\section{BIOGRAPHICAL INFO}

Q1: $\quad$ Age

Q2: Indicate your gender:

$$
\text { Male }
$$$$
\text { Female }
$$

Q3: Home language(s)

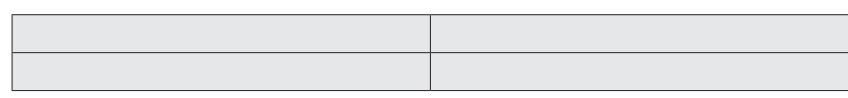

Q4: School attended:

\section{SECTION B:}

\section{READING HISTORY}

Q5: How much do you agree with the following statements?

\section{Q5.1: I love to read.}

\begin{tabular}{|l|l|}
\hline Strongly agree & \\
\hline Agree & \\
\hline Neutral & \\
\hline Disagree & \\
\hline Strongly disagree & \\
\hline
\end{tabular}

Q5.2: I only really read books when I have to for school or university work.

\begin{tabular}{|l|l|}
\hline Strongly agree & \\
\hline Agree & \\
\hline Neutral & \\
\hline Disagree & \\
\hline Strongly disagree & \\
\hline
\end{tabular}

\section{Q5.3: As a child my parents read to me.}

\begin{tabular}{|l|l|}
\hline Strongly agree & \\
\hline Agree & \\
\hline Neutral & \\
\hline Disagree & \\
\hline Strongly disagree & \\
\hline
\end{tabular}

Q6:

Do you have a bookcase/shelf at home?

\begin{tabular}{l|r} 
yes & no
\end{tabular}

\section{Q6.1: Is it used regularly?}

$$
\text { yes }
$$

\section{SECTION B:}

\section{READING HABITS AND PREFERENCES}

Q7: How often do you read books for pleasure (i.e. not for school/university work)?

\begin{tabular}{|l|l|}
\hline I try to read everyday & \\
\hline Once or twice a week & \\
\hline Every few months & \\
\hline Once a year & \\
\hline Hardly ever & \\
\hline Never & \\
\hline
\end{tabular}

Q8: $\quad$ For the following categories, please name your favourite (for example under magazine you might say 'Popular Mechanic Magazine').

\begin{tabular}{|l|l|}
\hline Novels & \\
\hline Non-fiction books (biographies etc) & \\
\hline Magazines & \\
\hline Newspapers (print \& online) & \\
\hline Online (websites, blogs, chatting) & \\
\hline
\end{tabular}

Q9: $\quad$ Please state what it was that you last read in each of these categories (for example, under magazine you might say 'Popular Mechanic Magazine' because it was the last magazine you read). Answer all categories:

Key:

$$
\begin{aligned}
& 1 \text { - in the last } 2 \text { to } 3 \text { days } \\
& 2 \text { - in the last } 2 \text { weeks } \\
& 3 \text { - last month } \\
& 4 \text { - a few months ago } \\
& 5 \text { - a year ago } \\
& 6 \text { - so long ago I can't remember }
\end{aligned}
$$

\begin{tabular}{|l|l|l|}
\hline Text & What you last read & $\begin{array}{l}\text { When (refer to } \\
\text { key below) }\end{array}$ \\
\hline Novels & & \\
\hline $\begin{array}{l}\text { Non-fiction books } \\
\text { (biographies etc) }\end{array}$ & & \\
\hline Magazines & & \\
\hline $\begin{array}{l}\text { Newspapers (print \& } \\
\text { online) }\end{array}$ & & \\
\hline $\begin{array}{l}\text { Online (websites, blogs, } \\
\text { chatting) }\end{array}$ & & \\
\hline
\end{tabular}

Q10: General comment on the role of reading and books in your life. 


\section{Appendix B}

Reading survey (2012): My holiday reading list

Please note that this will not affect your marks. Please write you name on this sheet so that we can check this against the informed consent form you signed at the beginning of the year and exclude those who do not want to participate.

Q1: Name:
Q2: Please write down what books you read during the June/July holidays. If you did not read any books, please write 'none'.

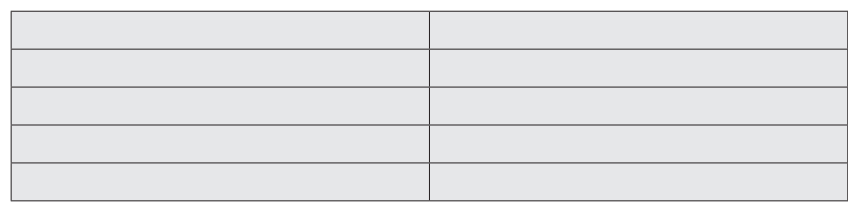

Thank you for participating 